\title{
Studies on the nutrition of marine flatfish. The pyridoxine requirement of turbot (Scophthalmus maximus)
}

\author{
BY J. W. ADRON, D. KNOX AND C. B. COWEY \\ Institute of Marine Biochemistry, St Fittick's Road, Aberdeen ABI $3 R A$ \\ AND G. T. BALL \\ Fisheries Laboratory, Breakwater Road, Port Erin, Isle of Man
}

(Received 28 October 1977 - Accepted 22 February 1978)

\begin{abstract}
I. Diets containing graded levels of pyridoxine hydrochloride (to supply $0.26-30 \mathrm{mg}$ pyridoxine $/ \mathrm{kg}$ ) were given to seven duplicate groups of turbot (Scophthalmus maximus) for 12 weeks and their growth rate was measured during this period.

2. Good growth was obtained on all treatments except those groups given less than $\mathrm{I} \cdot 0 \mathrm{mg}$ pyridoxine $/ \mathrm{kg}$ diet. These fish grew normally until weeks 8-10 but thereafter their weight gain was significantly less than that for other treatments.

3. Measurements of aspartate aminotransferase (EC 2.6. I. I) in muscle and liver and of alanine aminotransferase (EC 2.6.1.2) in liver of the turbot showed that the activities of these enzymes increased with increasing dietary pyridoxine intake up to a level of $2.5 \mathrm{mg}$ pyridoxine $/ \mathrm{kg}$. The activities of these enzymes were not further enhanced by additional dietary pyridoxine.

4. Percentage stimulation of these enzymes by pre-incubation of extracts with pyridoxal phosphate was minimal with those groups of turbot given $2.5 \mathrm{mg}$ pyridoxine $/ \mathrm{kg}$ diet or more.

5. It is concluded that the dietary requirement of turbot for vitamin $B_{6}$ can be safely met with a diet containing between $\mathrm{I} \cdot 0$ and $2.5 \mathrm{mg}$ pyridoxine $/ \mathrm{kg}$.

6. An eighth group of turbot given the pyridoxine antagonist 4-deoxypyridoxine hydrochloride $(20 \mathrm{mg} /$ $\mathrm{kg}$ ) showed retarded growth after 2 weeks, together with a high mortality rate.
\end{abstract}

A dietary requirement for pyridoxine has been demonstrated in several species of freshwater and marine fish; chinook salmon (Oncorhynchus kisutch) (Halver, 1957), channel catfish (Ictalurus punctatus) (Dupree, I966), silver salmon (Oncorhynchus tshawytscha) (Coates \& Halver, I958), and yellowtail (Seriola quinqueradiata) (Sakaguchi, Takeda \& Tange, 1969). Signs of pyridoxine deficiency begin to appear after 2-9 weeks in fish given diets lacking or deficient in pyridoxine. They include poor growth, anorexia, ataxia, oedema and epileptiform fits and other nervous disorders.

Quantitative requirements have been determined by feeding the fish diets containing graded levels of pyridoxine; for the red sea bream (Chrysophrys major) (Takeda \& Yone, 197I) and the carp (Cyprinus carpio) (Ogino, 1965) these were 5-6 mg pyridoxine/ $\mathrm{kg}$ diet and $5.4 \mathrm{mg}$ pyridoxine $/ \mathrm{kg}$ diet respectively. By contrast a level of $10-20 \mathrm{mg}$ pyridoxine $/ \mathrm{kg}$ diet is required by rainbow trout (Salmo gairdneri), brook trout (Salvelinus fontinalis), brown trout (Salmo trutta), chinook salmon and coho salmon (Oncorhymchus kisutch) (Halver, I972). These latter requirements were based on measurements of growth response and maximum liver storage of vitamin $B_{6}$.

Tissue aminotransferase levels have been used to assess the pyridoxine status of several animals, including the rat (Brin, Tai, Ostashever \& Kalinsky, I960) and chick (Sifri, Daghir \& Asmar, 1972). Both groups of workers found tissue aminotransferase levels to be a useful and sensitive measure of pyridoxine sufficiency. Ogino (1965) found with carp that the activities of liver aspartate aminotransferase (EC 2.6. I I ; GOT) and alanine aminotransferase ( $E C$ 2.6. 1 .2; GPT) were influenced by the pyridoxine intake and a similar result was obtained by Takeda \& Yone (1971) with the red sea bream. A study of pyridoxine 
deficiency in the rainbow trout (Smith, Brin \& Halver, 1974) demonstrated that erythrocyte alanine aminotransferase activity was decreased during pyridoxine deficiency. From the previously-mentioned results tissue aminotransferase activity appears a useful supplementary technique in assessing the pyridoxine requirement of fish.

The present studies were aimed at measuring the pyridoxine requirement of a marine fish, the turbot (Scophthalmus maximus) from dose $v$. response curves using both growth results and tissue aminotransferase activities. Thus seven duplicate groups of fish were given diets containing graded levels of pyridoxine hydrochloride (to supply $0 \cdot 26-30 \mathrm{mg}$ pyridoxine/ $\mathrm{kg}$ dry diet). A further two groups of fish were given diets containing the pyridoxine antagonist 4-deoxypyridoxine hydrochloride $(20 \mathrm{mg} / \mathrm{kg} \mathrm{diet}$ ). From these experiments the pyridoxine requirement of the turbot was found to be between $\mathrm{I} \cdot 0$ and $2.5 \mathrm{mg}$ pyridoxine $/ \mathrm{kg}$ dry diet.

\section{EXPER IMENTAL}

The fish used in the experiment were turbot reared from the egg at Port Erin, Isle of Man, as described by Jones (1973). After metamorphosis the turbot were given diets composed mainly of minced trash fish. Before the start of the experiment the fish were marked on the ventral surface by sub-dermal injections of different-coloured latex dyes, making them individually identifiable. The turbot were then distributed between sixteen black polyethylene tanks ( $\mathrm{I} .20 \times 0.60 \times 0.03 \mathrm{~m}$ deep) six fish to each tank. They were then weaned to a pelleted diet (diet 7, Tables I and 2) for a period of 6 weeks. Most of the turbot readily accepted the pelleted diet: any fish that failed to do so were rejected.

After weaning the fish were re-allocated between the sixteen tanks as previously described (Cowey, Adron, Knox \& Ball, 1975). The biomass in each of the sixteen tanks was similar (Table 3). An analysis of variance of the initial weight distribution between each group showed no significant differences.

The fish were fed at 08.30 and 16.30 hours each day as described previously (Cowey et al. I975). The fish were weighed, using the procedure described by Cowey, Adron, Blair \& Shanks (1974), at 2-weekly intervals throughout the I 2-week experiment. The 'flow-through' sea-water aquarium system was housed in a constant temperature room in which both air and sea-water temperatures were maintained at $18 \pm 0.5^{\circ}$.

Diets were prepared at The Institute of Marine Biochemistry, Aberdeen, as described by Cowey, Pope, Adron \& Blair (1972). They were made into moist pellets by extrusion through a perforated plastic plate fitted into a meat mincer (Model A200; The Hobart Manufacturing Co. Ltd, Hobart Corner, New Southgate, London). The diets were stored at $-15^{\circ}$ before transportation in solid carbon dioxide to Port Erin where they were kept at $-15^{\circ}$ until used.

The composition of the basal diet (diet $I$ ) is shown in Table $I$. When prepared, this diet was found to contain $0.26 \mathrm{mg}$ vitamin $\mathrm{B}_{6}$ activity $/ \mathrm{kg}$ dry diet, measured in terms of pyridoxine by microbiological assay with Kloeckera brevis (Barton-Wright, I97I). Further diets were prepared by adding graded levels of pyridoxine hydrochloride (Sigma (London) Chemical Co. Ltd, Norbiton, Surrey) to the basal diet. The pyridoxine contents of these diets were also measured by microbiological assay, and are shown in Table 2. Diet 8 was prepared from the basal diet by the addition of the pyridoxine antagonist 4-deoxypyridoxine hydrochloride (Sigma (London) Chemical Co. Ltd) at $20 \mathrm{mg} / \mathrm{kg}$.

Although considerable care was taken in the feeding of the turbot (for details, see Cowey et al. 1975) some leaching of some of the water-soluble components from some of the pellets probably occurred. Thus the dose $v$. response curve obtained from the experiment may if anything tend to over-estimate the dietary level of pyridoxine $\mathrm{n}^{\wedge}$ cessary to meet the vitamin $B_{6}$ requirement of turbot.

At the end of the experimental period, all the fish from each treatment were killed by 
Table I. Composition $(\mathrm{g} / \mathrm{kg})$ of the basal diet given to turbot

(Scophthalmus maximus)

\begin{tabular}{lr} 
Fish-protein concentrate* & 313 \\
Casein, vitamin-free $\dagger$ & 250 \\
Dextrin & 50 \\
Glucose & 50 \\
Cod-liver oil & 20 \\
Herring oil & 60 \\
Mineral premix \\
Vitamin premix & 5 \\
$\alpha$-Cellulose $\dagger$ & 28 \\
Methionine & 157 \\
Arginine & 10 \\
Edifas $\|$ & 7 \\
\hline
\end{tabular}

* Protanimal; Astra Chemicals Ltd, Watford, Herts.

$\uparrow$ Nutritional Biochemicals, Cleveland, Ohio.

† Supplied (mg/kg dry diet): $\mathrm{Ca}\left(\mathrm{H}_{2} \mathrm{PO}_{4}\right)_{2} . \mathrm{H}_{2} \mathrm{O} 400, \mathrm{CaCO}_{3} \mathrm{I000}$, ferric citrate (hydrated) $100, \mathrm{MgSO}_{4}$. $7 \mathrm{H}_{2} \mathrm{O} 400, \mathrm{~K}_{2} \mathrm{HPO}_{4} 700, \mathrm{Na}_{2} \mathrm{HPO}_{4} . \mathrm{H}_{2} \mathrm{O} 250, \mathrm{AlCl}_{3} .6 \mathrm{H}_{2} \mathrm{O} 20, \mathrm{ZnCl}_{2} 60, \mathrm{CuSO}_{4} \cdot 5 \mathrm{H}_{2} \mathrm{O} 30, \mathrm{MnSO}_{4} \cdot 4 \mathrm{H}_{2} \mathrm{O}$ $20, \mathrm{KI} 20, \mathrm{CoCl}_{2} .6 \mathrm{H}_{2} \mathrm{O} 30$.

$\S$ Supplied (/kg diet): riboflavin $200 \mathrm{mg}$, thiamin hydrochloride $50 \mathrm{mg}$, nicotinic acid $800 \mathrm{mg}$, calcium pantothenate $500 \mathrm{mg}$, myo-inositol $2 \mathrm{~g}$, biotin $5 \mathrm{mg}$, pteroylmonoglutamic acid $15 \mathrm{mg}$, choline bitartrate $9 \mathrm{~g}$, ascorbic acid $2 \mathrm{~g}$, DL- $\alpha$-tocopheryl acetate $400 \mathrm{mg}$, menaphthone $40 \mathrm{mg}$, cyanocobalamin $90 \mu \mathrm{g}$.

|| ICI Ltd, Ardrossan, Ayrshire.

Table 2. Pyridoxine content $(\mathrm{mg} / \mathrm{kg})$ of the experimental diets given to turbot (Scophthalmus maximus)

$\begin{array}{cc}\text { Diet no.* } & \begin{array}{c}\text { Total pyridoxine } \\ \text { content }\end{array} \\ \text { I } & 0.26 \\ 2 & 0.50 \\ 3 & 1.00 \\ 4 & 2.50 \\ 5 & 5.00 \\ 6 & 10.00 \\ 7 & 30.00 \\ 8 \dagger & 0.26\end{array}$

* The basal diet (diet I; for details, see Table I) was supplemented with graded amounts of pyridoxine hydrochloride.

$\dagger 4$-Deoxypridoxine hydrochloride $(20 \mathrm{mg} / \mathrm{kg}$ ) only was added to the basal diet.

¥ As measured by microbiological assay with Kloeckera brevis (Barton-Wright, I97I).

a sharp blow on the head. Blood samples were taken from the caudal vein of each fish using disposable syringes that had been previously rinsed with a solution of ethylenediaminotetraacetic acid, disodium salt (100 g/l). Packed cell volumes were determined on small quantities of blood from each fish using heparinized capillary tubes and a microhaematocrit centrifuge (Hawksley \& Sons Ltd, Lancing, Sussex). The remainder of each blood sample was mixed with $10 \mathrm{mg}$ heparin (Sigma (London) Chemical Co. Ltd) and centrifuged for 2 min (Eppendorf centrifuge 3200; Eppendorf Gerätebau, Netheler Hinz GmbH). A sample of the plasma obtained was stored in solid $\mathrm{CO}_{2}$. Samples of muscle and liver for aminotransferase assays were also taken from each fish and immediately frozen in solid $\mathrm{CO}_{2}$ for transport to Aberdeen.

Tissues, muscle and liver for aminotransferase assays were thawed in cold $\mathrm{O} \cdot \mathrm{I}$ M-phosphate buffer, $\mathrm{pH}_{7.4}$ ( $\mathrm{I} \mathrm{g}$ tissue in $10 \mathrm{ml}$ buffer) before being homogenized (Potter homogenizer; Tri-R Instruments, Jamaica 35, N.Y., USA). The homogenates were centrifuged in an 


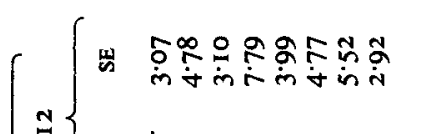

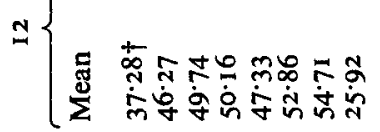

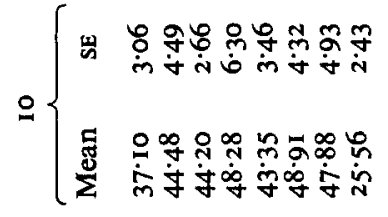

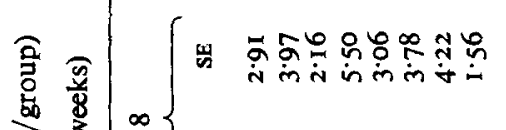

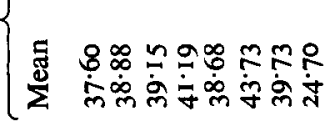

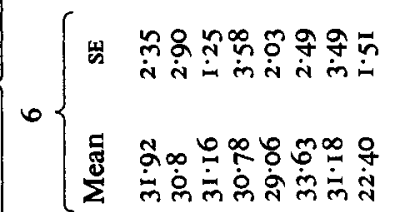

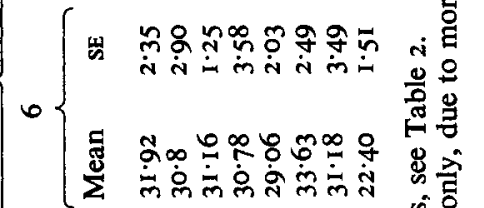
递导

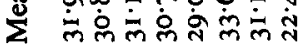

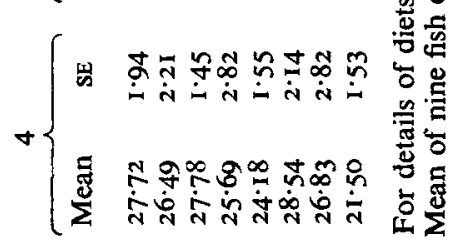

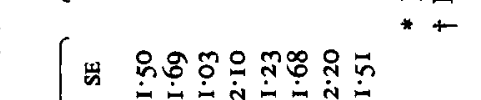

$\sim$

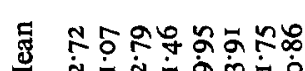

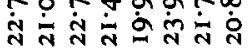

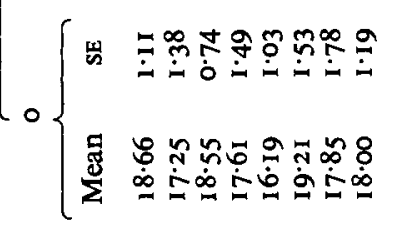

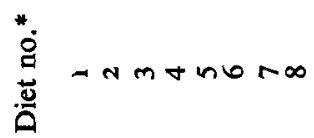

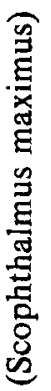

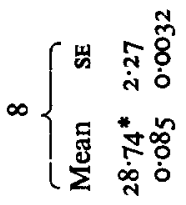

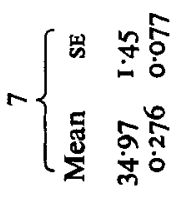

‡

荌

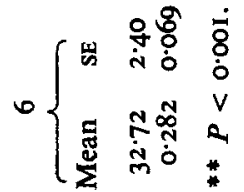

要

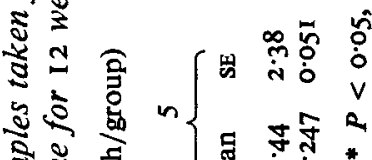

密.

ปั

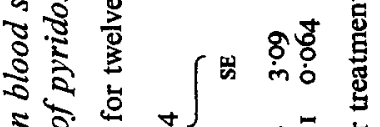

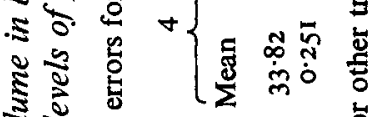

焉焉

马ं

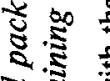

จิ

इ

है

离 


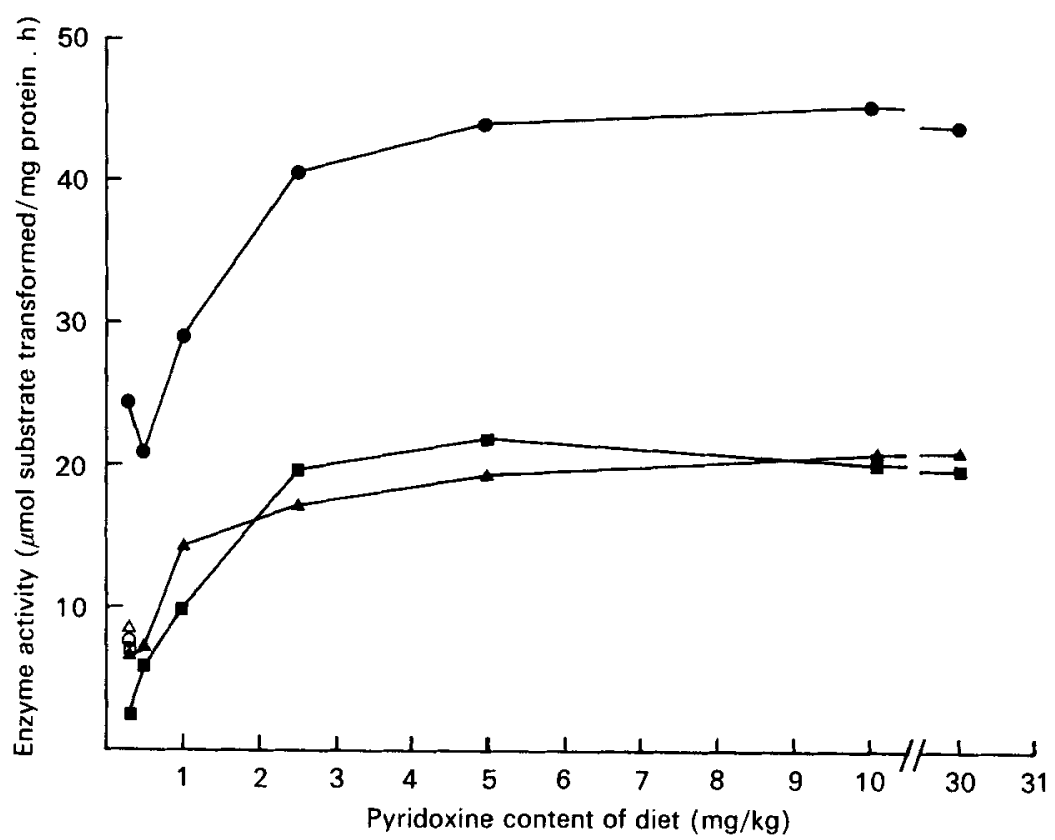

Fig. I. Activities ( $\mu \mathrm{mol}$ substrate transformed $/ \mathrm{mg}$ protein per $\mathrm{h}$ ) of aspartate aminotransferase $(E C$ 2.6. I . I ) in liver $(-))$ and muscle $(\Delta-\Delta)$ and of alanine aminotransferase $(E C 2.6 .1 .2)$ in liver ( $\square-\mathbf{B})$ of turbot (Scophthalmus maximus) given diets containing graded amounts of pyridoxine for 12 weeks. Values for turbot given diets containing deoxypyridoxine are also shown: $(O)$, aspartate aminotransferase, liver; $(\triangle)$, aspartate aminotransferase, muscle; ( $\square$ ), alanine aminotransferase, liver.

Eppendorf centrifuge and the supernatant fractions obtained were used for assay. Both liver and muscle supernatant fractions were assayed for GOT activity, using the method of Bergmeyer \& Bernt (1970a). Liver superantant fractions alone were assayed for GPT activity, using the method of Bergmeyer \& Bernt ( $1970 b)$. The aminotransferase assays were carried out both on the extract as prepared and on portions of the extract which had been incubated with $3 \mathrm{mM}$-pyridoxal phosphate for $30 \mathrm{~min}$ at $25^{\circ}$ (Chen \& Marlatt, 1975).

The protein content of the liver and muscle homogenates and of the plasma was determined by the method of Lowry, Rosebrough, Farr \& Randall (I95I) as modified by Schuel \& Schuel (1967).

\section{RESULTS}

The mean body-weights of the turbot throughout the experimental period are shown in Table 3. Visual inspection of the values obtained reveals that all groups increased in weight up to week 8; thereafter neither turbot given diet no. I nor those given diet no. 8 increased significantly ( $t$ test within each diet comparing week to and week 8). Similarly turbot given diet no. 2 did not increase significantly in weight in the final weeks of the experiment $(t$ test within diet groups nos. 2-7 comparing week 12 with week 10 ).

Thus turbot given diet no. I grew normally up to week 8 but thereafter growth ceased and mortalities ensued between weeks 10 and 12 ; turbot given diet no. 2 did not increase significantly in weight between weeks 10 and 12 while those fish given diet no. 8 gave a significantly depressed rate of growth to a maximum weight at about 9 weeks. There were no significant differences between the other five treatments. 


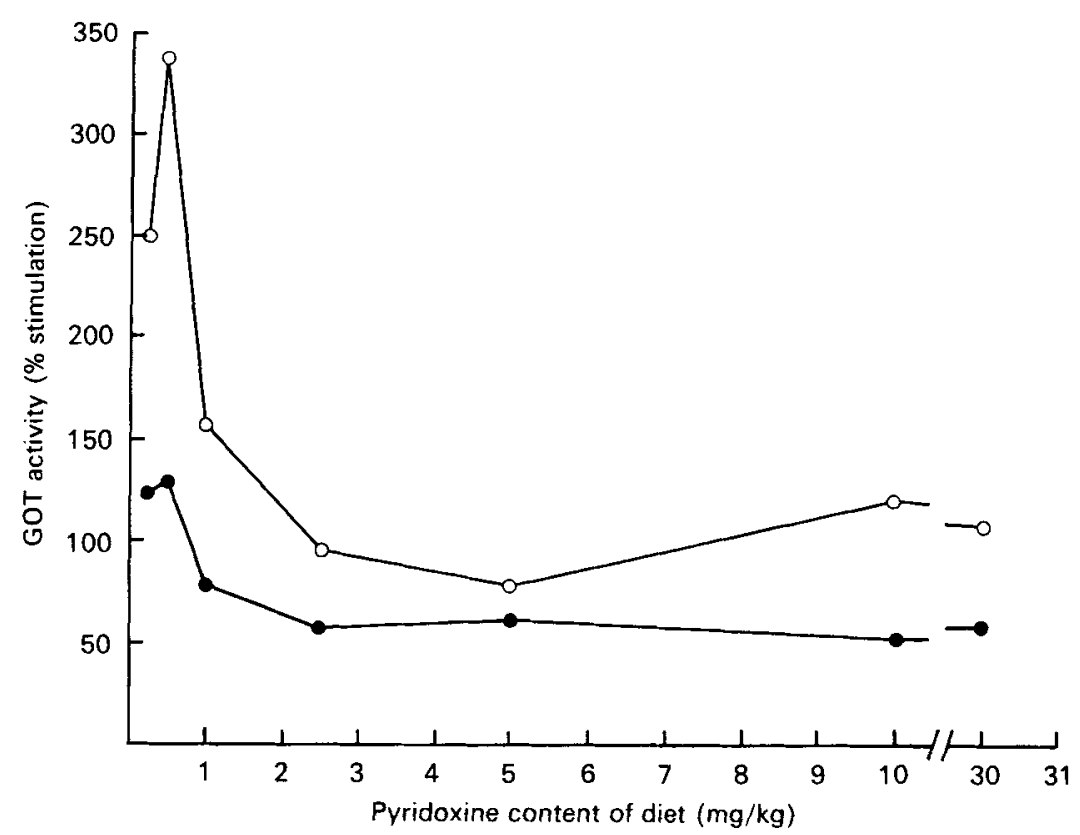

Fig. 2. Percentage stimulation (by pre-incubation of the extract with pyridoxal phosphate; for details, see p. 265) of aspartate aminotransferase ( $E C$ 2.6. I I ; GOT) activity in liver ( - - and in muscle $(\mathrm{O}-\mathrm{O})$ of turbot (Scophthalmus maximus) given diets containing graded levels of pyridoxine for 12 weeks. For details of diets, see Table $\mathrm{I}$.

Packed cell volumes and plasma protein values for each dietary treatment are shown in Table 4. There were no significant differences between the turbot receiving graded levels of dietary pyridoxine. However, in the fish given diet no. 8, containing deoxypyridoxine the plasma protein level decreased and the packed cell volume was also reduced.

The activities of liver and muscle GOT and liver GPT are shown in Fig. I. The activity of each of these enzymes was significantly less in those fish given diets nos. I, 2 and $3(0.26$, 0.5 and $\mathrm{I} .0 \mathrm{mg}$ pyridoxine $/ \mathrm{kg}$ diet $)$ than in fish given diets nos. 4-7 (2.5 $\mathrm{mg}$ or more pyridoxine $/ \mathrm{kg}$ diet). The activities of GOT and GPT were reduced in turbot given diet no. 8 containing deoxypyridoxine. Mean $( \pm \mathrm{SE}$ ) values for GOT being $14.77 \pm 0.4 \mathrm{I}$ and $6.93 \pm$ $0.68 \mu \mathrm{mol}$ substrate transformed/mg protein per $\mathrm{h}$ for liver and muscle respectively; GPT activity in the liver was II II $\pm 0.97 \mu \mathrm{mol}$ substrate transformed/mg protein per $\mathrm{h}$.

The percentage stimulation of muscle and liver GOT activity, after pre-incubation of the extracts with pyridoxal phosphate, is shown in Fig. 2. Stimulation was highest in turbot receiving diets containing less than $2.5 \mathrm{mg}$ pyridoxine $/ \mathrm{kg}$ diet (diets nos. $\mathrm{I}, 2,3$ ). However, even for those fish that received the highest level of dietary pyridoxine, there was still a marked stimulation of enzyme activity, after pre-incubation of the extract with pyridoxal phosphate. Stimulation of liver and muscle GOT by pre-incubation of the tissue extracts with pyridoxal phosphate was lowest in turbot given diet no. 8 , mean ( \pm SE) percentage stimulation of liver GOT in these fish being $46 \cdot 4 \mathrm{I} \pm 5 \cdot 45$ and that of muscle GOT $53 \cdot 68 \pm 5 \cdot 42$. These compare with values of $123.5 \pm 6 \cdot I$ and $149 \cdot 3 \pm 8 \cdot 4$ for fish given diet no. I containing the same level of pyridoxine hydrochloride but no deoxypyridoxine. 


\section{DISCUSSION}

From the values for weight gain the present results indicate that the vitamin $B_{6}$ requirement of turbot is satisfied by diets containing between 0.5 and $1.0 \mathrm{mg}$ pyridoxine $/ \mathrm{kg}$ diet. This level is lower than that required by red sea bream (Takeda \& Yone, 1971) and carp (Ogino, 1965) and much lower than that required by several species of freshwater fish (Halver, 1972).

Many vitamins function, either as such or in a modified form, as coenzymes and measurements of relevant tissue enzyme activities have frequently been used to provide supplementary evidence concerning the requirement of an animal for a given vitamin. Hence the measurement of GOT and GPT in the present experiment. However pyridoxal phosphate serves as a coenzyme for many enzymes and there is at present no means of knowing which of these enzymes is most critically affected by the stress of a restricted vitamin $B_{6}$ intake. In other words the use of enzyme saturation procedures to estimate vitamin nutritional status will be influenced by the choice of enzyme system. Nevertheless the GOT and GPT activities reported here are of interest in that they demonstrate that maximal levels of activity were reached at a lower dietary pyridoxine intake $(2.5 \mathrm{mg} / \mathrm{kg})$ than is the situation with other species of fish. To this extent they support the weight-gain results.

Referring to the percentage stimulation of enzyme activity after pre-incubation of tissue extracts with pyridoxal phospate, it is noteworthy that, even at the highest dietary levels of pyridoxine used, this procedure still led to an increase in aminotransferase activity even though total tissue aminotransferase activity ceased to increase in response to increments of dietary pyridoxine at much lower dietary pyridoxine levels (Figs. I and 2). Similar results were obtained by Sifri et al. (1972) using chicks; they appeared to favour the explanation that enhancement of aminotransferase activity by pre-incubation of extracts was due, not only to complete saturation of apoenzyme in the extract by pyridoxal phosphate, but also to a non-enzymic reaction involving pyridoxal phosphate and metal ions as suggested by Sauberlich (I968).

Deoxypyridoxine has long been known as a potent vitamin $B_{6}$ antagonist in chicks and rats. In vitro studies showed that deoxypyridoxine can be phosphorylated by pyridoxal kinase (EC 2.7.I.35) to deoxypyridoxine 5'-phosphate which inhibits pyridoxal-P enzymes (Hurwitz, 1955). This has been considered a probable explanation of the vitamin $B_{6}$ antagonism of deoxypyridoxine although the effects of deoxypyridoxine treatment on some liver aminotransferases differ from those of a vitamin $B_{6}$ deficiency (Caldwell \& McHenry, 1953).

In the present experiments deoxypyridoxine was used as a possible means of demonstrating an absolute requirement by turbot for pyridoxine: an attempt to guard against the possibility that the level of pyridoxine in the basal diet $(0.26 \mathrm{mg} / \mathrm{kg})$ might have been adequate to meet the needs of the fish. In the event this was unnecessary as a pyridoxine requirement was shown in the growth experiment.

The level of deoxypyridoxine used in diet no. $8(20 \mathrm{mg} / \mathrm{kg})$ was much lower than that ( $\mathrm{I} / \mathrm{kg}$ ) used to exacerbate clinical symptoms of vitamin $B_{6}$ deficiency in mammals (Coburn, Mahuren \& Sallay, 1976). Even so the turbot given this diet had a high mortality rate, retarded growth, low packed cell volumes, reduced plasma proteins levels; histopathology was restricted to the kidney where tubule cells were atrophying, sloughing off and tending to block the tubule lumen. These symptoms may indicate that in addition to acting as a competitive antagonist of pyridoxine (as shown by the decrease in aminotransferase activity in these fish) deoxypyridoxine exerted other (possibly toxic) metabolic effects in these turbot. Unfortunately there were neither sufficient tanks nor fish available to examine the combined effects of pyridoxine hydrochloride and deoxypyridoxine in the same diet; that is, to see whether the effects of deoxypyridoxine were repressed by pyridoxine. 


\section{REFERENCES}

Barton-Wright, E. C. (1971). Analyst, Lond. 96, 314.

Bergmeyer, H. U. \& Bernt, E. (1970a). In Methoden der enzymatischen Analyse, vol. I, 2nd ed., p. 685 [H. U. Bergmeyer, editor]. Weinheim: Verlag Chemie.

Bergmeyer, H. U. \& Bernt, E. (1970 b). In Methoden der enzymatischen Analyse, vol. I, 2nd ed., p. 717 [H. U. Bergmeyer, editor]. Weinheim: Verlag Chemie.

Brin, M., Tai, M., Ostashever, A. S. \& Kalinsky, H. (I 960). J. Nutr. 71, 416.

Caldwell, E. F. \& McHenry, E. W. (1953). Archs Biochem. Biophys. 45, 466.

Chen, L. H. \& Marlatt, A. Y. (1975). J. Nutr. 105, 401.

Coates, J. A. \& Halver, J. E. (1958). U.S. Fish Wildl. Serv. Bur. Sport Fish Wildl. Spec. Sci. Rep. Wildl. 281, I.

Coburn, S. P., Mahuren, J. D. \& Sallay, S. I. (1976). J. biol. Chem. 251, 1646.

Cowey, C. B., Adron, J. W., Blair, A. \& Shanks, A. M. (1974). Br. J. Nutr. 31, 297.

Cowey, C. B., Adron, J. W., Knox, D. \& Ball, G. T. (1975). Br. J. Nutr. 34, 383.

Cowey, C. B., Pope, J. A., Adron, J. W. \& Blair, A. (1972). Br. J. Nutr. 28, 447.

Dupree, H. K. (1966). Tech. Pap. Bur. Sport Fish Wildl. 7, 3.

Halver, J. E. (1957). J. Nutr. 62, 225.

Halver, J. E. (editor) (1972). In Fish Nutrition, p. 29. London: Academic Press Inc. (London) Ltd.

Hurwitz, J. (1955). J. biol. Chem. 217, 513.

Jones, A. (1973). Aquaculture, 2, 149.

Lowry, O. H., Rosebrough, N. J., Farr, A. L. \& Randall, R. J. (195I). J. biol. Chem. I93, 264.

Ogino, C. (1965). Bull. Jap. Soc, scient. Fish. 3x, 546.

Ott, W. H. (1946). Proc. Soc. exp. Biol. Med. 61, 125.

Sakaguchi, H., Takeda, F. \& Tange, K. (1969). Bull. Jap. Soc. scient. Fish. 35, I 201.

Sauberlich, H. E. (1968). In The Vitamins, vol. 2, 2nd ed., p. 44 [W. H. Sevrell Jr and R. S. Harris, editors]. New York: Academic Press.

Schuel, H. \& Schuel, P. (1967). Analyt. Biochem. 20, 86.

Sifri, M., Daghir, N. J. \& Asmar, J. A. (1972). Br. J. Nutr. 28, 173.

Smith, C. E., Brin, M. \& Halver, J. E. (1974). J. Fish. Res. Board Can. 31, I 893.

Takeda, T. \& Yone, Y. (1971). Rep. Fish Res. Lab., Kyushu Univ. no. 1, 37. 